\title{
ISLAMIC CHARITIES AND DAKWAH MOVEMENTS IN A MUSLIM MINORITY ISLAND The Experience of Niasan Muslims ${ }^{1}$
}

\author{
Hilman Latief \\ Muhammadiyah University of Yogyakarta - Indonesia
}

\begin{abstract}
This paper discusses the roles of Islamic charitable organisations in running dakwah activities on Nias Island. By Showing how Islamic charitable organizations have attempted to create welfare programmes under the dakwah scheme, it investigates whether inclusive attitudes towards beneficiaries with different religious backgrounds have characterised Islamic social activism in 'non-Islamic' regions. As a Muslim minority area, postdisaster Nias Island has increasingly become a place where Islamic charitable associations and dakwah movements from outside Nias have attempted to deliver aid as well as to assist the communities, notably the Muslim minority population. As the outer islands and isolated regions have become an arena of contestation for religious missionaries, Muslim preachers to a certain extent should compete with Christian missionaries and indigenous religious groups. By way of a case study, this paper also examines the way in which Islamic charitable associations, negotiate between serving the Muslim community through dakwah, and serving humanity at large through social welfare activities.
\end{abstract}

Keywords: Muslim minority, dakwah, Islamic charity.

\section{Introduction}

\footnotetext{
${ }^{1}$ The earlier version of this paper was presented at The $12^{\text {th }}$ Annual International Conference on Islamic Studies (AICIS), held by the Ministry of Religious Affairs and the State Institute of Islamic Studies (IAIN) Sunan Ampel, Surabaya, 5-8 November 2012.
} 
Like other small outer islands, which are far from the heartland of Indonesian economic and political power, Nias Island is considered an unattractive place by Indonesians and the central government. The Nias archipelago_including the Hinako archipelago-comprises 132 islands, 95 of which are uninhabited. Nias Island, or Tanö Niba, is the largest island of the Nias archipelago, with Gunung Sitoli as its district capital. Based on the 2000 population census, the Nias ethnic group Ono Niha counts for only $0.36 \%$ (731,620 people) of the whole of Indonesia's population, but is the third largest ethnic group in North Sumatra $(6.36 \%)$ after the Batak (41.95\% or 4,827,264 people) and Javanese $\left(32.62 \%\right.$ or $3,753,947$ people). ${ }^{2}$ According to the 2009 Statistic Bureau report, Nias Island then had 443,492 inhabitants. ${ }^{3}$

Administratively, the Nias Regency (Kabupaten Nias) is included in the Province of North Sumatra, and in early 2003, this island was divided into two autonomous regencies: North Nias Regency and South Nias Regency, with Gunung Sitoli and Teluk Dalam as their respective capital cities. Following the implementation of the Government Ordinance of Regional Autonomy, Nias Island is now divided into four Regencies (Gunung Sitoli Municipality, Nias Regency, North Nias Regency, and West Nias Regency). Despite its beautiful landscape, this area has remained relatively untouched by international and even domestic tourism, unlike, for example, Bali and the Lombok islands. Yet, since the end of 2004, Nias has received extensive coverage in the media after it was badly affected by the devastating tsunami and earthquake of December 2004 and March 2005 respectively. As these natural disasters left a trail of devastation behind them, various social, religious, and relief associations landed in Nias in order to reach and help the victims.

The social and economic rhythm of the Niasans suddenly changed after the natural disasters resulted in a flow of domestic and international funds to the region, brought by various NGOs. Along with the government's reconstruction team, both domestic and international NGOs have provided relief supplies and managed social, economic, and physical reconstruction programs. Some relief NGOs only supervised short-term plans, providing goods and supplies for

${ }^{2}$ Leo Suryadinata, Evi Nurvidya Arifin and Aris Ananta, Indonesia's Population: Ethnicity and Religion in a Changing Political Landscape (Singapore: ISEAS, 2003).

3 BPS Kabupaten Nias, Nias dalam Angka/Nias in Figure (Nias-Gunung Sitoli: BPS, 2009), p. 47. 
victims, while others continue to run long-term social and economic development projects, focusing on sustainable livelihoods. Meanwhile, large-scale reconstruction projects are predominantly supervised by the government, government NGOs (G-NGOs), and international NGOs. Various local institutions, such as religious associations, NGOs, and social institutions have played pivotal roles in forging partnerships with domestic and international NGOs operating in Nias.

New developments in the social, cultural, religious, and economic domains can also be seen in post-disaster Nias. The flow of foreign funds brought by 'outsiders' (i.e. international NGOs and foreign donors) over the last three years, for example, has had a great impact on the socio-economic life of this island, as considerable growth in the reconstruction sector has been followed by an increase in wages for people residing in rural and urban Nias. The contact between local people and foreigners can also be said to have influenced the Niasans' views on life and traditions, and even their religious belief systems. It has been reported by local religious and social activists that the numbers of charismatic churches on Nias, representing a 'revivalmessianic-nativistic' movement, increased rapidly after local people came into closer contact with faith-based NGOs and evangelist groups. ${ }^{4}$ Likewise, as a result of the disaster, Niasan Muslims now have a greater connection with new domestic and international Islamic associations, such as zakat agencies, dakwah associations, and certain international Islamic charitable foundations.

Exploring the dynamics of Muslim social and religious activism in Nias is interesting to pursue because Muslim communities have often been overlooked in the existing studies of Nias. History, culture, language, ethnicity, and the architecture of indigenous Niasans have been studied by scholars for many years. ${ }^{5}$ This paper will focus on the

\footnotetext{
${ }^{4}$ Interview with some local NGOs' staff, social activists, and religious leaders during my fieldwork on Nias Island in February 2009 and October 2010.

5 Anthropologist Andrew Beatty, for example, has conducted extensive ethnographic studies on the contemporary culture and society of Nias. While Beatty's work is theoretically enriching for the understanding of characteristic of local groups, culture, kinship, families and religious practice, this book fails to even briefly highlight Muslim communities who in fact had been concentrated in the district capital of Nias (Gunung Sitoli) at the time the author conducted his field work in Nias during the 1980s. See Society and Exchange in Nias (Oxford: Oxford Studies in Social and Cultural Anthropology, 1992). See also for example, Peter T. Suzuki, Critical Survey of Studies on the Anthropology of Nias, Mentawai and Enggano (Leiden: KITLV, 1958); also his "Niasans
} 
roles played by domestic and international Muslim NGOs that operate in Muslim minority regions such as Nias, and will explore the way in which those NGOs, including zakat agencies and charitable institutions, formulate their programmes and activities in order to help the Muslim minority in Nias. In particular, this paper analyses the roles of 'local actors', in other words the commoners, and how their informal networks have functioned in sustaining the operation of charitable works and development oriented-projects in certain regions of Nias. This paper argues that Muslim minority areas on outer islands like Nias have become places where Muslim charitable institutions and zakat agencies from outside Nias attempt to reconstruct and reformulate their understanding of zakat beneficiaries so that Muslim minorities in isolated regions are included. Thus, these institutions and agencies work to reshape and preserve the symbolic and cultural identities of Niasan Muslims.

\section{Dakwah and Giving Practice in Islam}

Islam is a religion of dakwah (mission), reminiscent of Christianity. Da'wa means 'call for Islam' or 'Islamic propagation'. In a broader context it also signifies social welfare and missionary activities. Islam came to the Indonesian archipelago centuries ago and has increasingly become a dominant religion since the $16^{\text {th }}$ century, its followers outnumbering those who adhere to Hinduism and Buddhism. Christianity came to the archipelago later on, and was first disseminated by Western missionaries during the colonial era. ${ }^{6}$ Islam is the predominant religion in Java and Sumatra, with parts of the North Sumatra as exceptions where German-oriented Protestantism is prevalent. In the other outer islands, Christianity is strongest, except in

of Batu Islands, Indonesia: A known but Neglected People," Bulletin of the International Committee on Urgent Anthropological and Ethnological Research, issue 12, (1970): pp. 61-69. Another extensive work relevant to this study, written by Uwe Hummel and Tuhoni Telaumbanua, focuses on the encounters between the indigenous traditions of the Niasans and the teachings of Christianity brought by missionaries. This book also briefly highlights the existence of Muslim communities in Nias but it does not analyse further the relation between Muslims and Christians in Nias, and Christians' rejection or reception of Islam in Nias. Uwe Hummel and Tuhoni Telaumbanua, Cross and Adu: a Socio-Historical Study on the Encounter between Christianity and the Indigenous Culture on Nias and the Batu Islands, Indonesia (1865-1965) (Zoetermeer: Boekencentrum, 2007).

${ }^{6}$ For one of the best works on the history of Christianity in modern Indonesia see Kareel Steenbrink, Catholics in Indonesia 1808-1942, vol. I (Leiden: KITLV Press, 2003). 
regions of long-time Muslim influence such as Borneo and South Celebes. Yet, there are areas where Muslims remain the minority, areas such as Papua, East Nusa Tenggara, Bali Island, North Sumatra, and Nias Island. Islamic associations, like the Muhammadiyah, Persatuan Islam, and Dewan Dakwah Islamiyah (DDII) were among the leading institutions to supervise missionary activities in isolated regions as a means of serving and strengthening the Muslim minority groups who were settled in non-Muslim majority areas.

Legitimised by the notion of the universal values of Islam (rahmatan li al-alamin), dakwah on the outer islands has become a major agenda for certain Islamic associations. The Muhammadiyah has run various missionary activities in isolated areas, including the area where Muslims migrants have settled, by being involved in the social and economic development processes in the areas. This Muslim modernist association, for example, has sent many $d \bar{a} i$ (Muslim preachers or missionaries) to assist the religious life of Muslims who transmigrated into these isolated areas. ${ }^{7}$ As the outer islands and isolated regions have become an arena of contestation for religious missionaries, Muslim missionaries to a certain extent compete with Christian missionaries and indigenous religious groups. ${ }^{8}$ Therefore, from a larger perspective, Islamic propagation in isolated areas can be seen as a contestation of the two largest religious groups in Indonesia: Islam and Christianity. Dewan Dakwah Islamiyah Indonesia (DDII) is institution that actively runs dakwah-related activities on outer islands. Established in Jakarta in 1967 by Mohammad Natsir, the prominent former Muslim politician, the DDII has until now been an active dakwah institution, not only in terms of supplying missionaries to Muslim minority areas, but also combating ‘Christianization' in Muslim majority areas. ${ }^{\text {' }}$

Conceptually, the ties between dakwah and Islamic forms of giving such as zakat (mandatory giving) and sadaqa (voluntary giving) show a rather intriguing issue. Islamic charitable institutions and zakat agencies that are able to mobilise domestic resources in Java have in fact

\footnotetext{
7 PP. Muhammadiyah, Badan da'wa; Bimbingan Masyarakat Terasing (Pimpinan Pusat Muhammadiyah, n.d.).

${ }^{8}$ See Goodwill Zubir and Sudar Siandes, Potret Gerakan Kristenisasi di Indonesia Versi Daí LDK Muhammadiyah (Pimpinan Pusat Muhammadiyah: Lembaga Dakwah Khusus, 2005).

9 "Genealogies of Islamic radicalism in post-Suharto Indonesia," South East Asia Research vol. 10, No. 2 (2002): pp. 117-154.
} 
expanded the scope of their operations by not limiting themselves to rural and urban areas on the mainland. Instead, they reach segments of beneficiaries on Nias Island. Among dozens of zakat agencies and charitable institutions that supervise dakwah activities in Nias, some institutions have come to the fore. The first is Al-Azhar Peduli, a community-sponsored zakat agency based in Jakarta and which is a social division of the Al-Azhar Mosque in Jakarta. This agency, which specialises in dakwah and education, has in recent times become one of the leading national zakat agencies in Indonesia. The activities of AlAzhar Peduli are very much associated with dakwah and education in general, and the reconstruction of mosques in particular. The intermediary roles played by zakat agencies in connecting 'the haves' with 'the have-nots', the needy with the wealthy, the disadvantaged groups of society with the well-off, have provided opportunity for the well-managed zakat agencies from other major cities of Indonesia, notably Jakarta, to determine beneficiaries on the outer islands.

The main form of Islamic giving, zakat, has eight specified types of beneficiaries: the poor, the needy, those whose hearts are inclined to Islam, the bond person/slaves, people in debt, the wayfarer, the zakat administrators, and those who follow in the way of God. From those listed beneficiaries, two of them-'those whose hearts are inclined to Islam' (mu'allaf qulübubum) and 'the bond person' (riqāb)- are in reality rarely included as zakat recipients. As far as the reports of zakat agencies in Indonesia are concerned, it is usual that the amount of zakat or sadaqa fund to be allocated for the two categories above is zero. This is simply due to the lack of a new innovation in interpreting the scope and meaning of mu'allaf qulübubum and riqāb in modern times. By contrast, the needy (fuqarā), the poor (miskin), and those who follow in the way of God ( $\bar{f}$ sabilillab) are among the entities that frequently receive support from zakat agencies. The term ' $\bar{f} \bar{i}$ sabilillah' has traditionally been interpreted as war in the way of God against the enemy of Islam, and thus this term is often coupled with jïhäd, struggling for or serious endeavors that Muslims can accomplish in order to uphold Islam. Thus jihäd fì sabilillah can mean rigorous attempts to fight in the way of God. While this kind of meaning remains accepted by Muslims, new reading of this term within Muslim communities also develops by attaching broader meaning. Fi sabilillah is then interpreted as an endeavor to support wide-ranging activities that are in line with God's order, such as to study Qur'an, to provide 
scholarship, and to provide adequate worship place (mosque), and to finance missionary activities (dakwab).

In coherence with this, I would argue that zakat agencies, such as Al-Az̧har Peduli and LAZ DDII, have defined the Muslim minority on the outer islands as being rakat and sadaqa beneficiaries, specifically classified as mu'allaf quiububum. It should be noted, however, that dakwah activities have also been legitimised by the notion of jiba $\bar{d} \bar{f}$ sabilillah ('struggling in the way of God'), a term which is often loosely interpreted by Muslims. In addition to this, the concept of poor or needy is often understood not only as a shortage in terms of material matters, but also spiritual. Muslim communities whose religiosity and religious knowledge are weak due to the shortage of Islamic education and absence of mosques, for example, can in part be regarded as being poor spiritually and therefore needing wide-ranging assistance.

\section{Al-Azhar Peduli (AAP): Reaching the Mu'allaf and Strengthening Dakwah}

Al-Azhar Peduli (AAP) is one of the community-based zakat agencies in Indonesia that have played extensive roles in collecting and distributing aid originating from Islamic social funds. This institution is attached to the Grand Mosque of Al-Azhar, one of the renowned mosques in Jakarta due to its historical background. The Al-Azhar Mosque is located in Kebayoran Baru, South Jakarta, and has been proclaimed by the local government as one of eighteen historical sites in Jakarta. In the 1950s, a number of Masyumi activists, supported by the Ministry of Social Affairs, Mr. Syamsuddin, set up an Islamic foundation, namely the Islamic Education Foundation (Yayasan Pendidikan Islam-YPI) on April 7, 1952. On November 19, 1953 the YPI started to build a mosque which was completed and first officially opened for public in 1958. The name of this mosque resembles another prominent mosque in Cairo, Egypt; the Al-Azhar Mosque. ${ }^{10}$ In recent times, Al-Azhar and the YPI have operated a wide-range of Islamic education institutions, ranging from kindergartens to

\footnotetext{
10 Professor Mahmoud Shaltout, the rector of Al-Azhar University of Cairo, who was invited to Al-Azhar Mosque suggested that it also be named Al-Azhar, to reflect the greatness of the mosque's construction at that time. The Al-Azhar Mosque in Jakarta has also become a spot where younger Muslim activists, under the Youth Islamic Study Club Al-Azhar (YISC), have vigorously organised discussions, seminars and conference since the 1970 s.
} 
universities, where Muslims among urban upper middle-class send their children to study. ${ }^{11}$

AAP and other zakat agencies have shared a similar set of programmes, such as charitable services, income generating projects, free healthcare provision, and scholarships. Yet, each zakat agency has put emphasis on certain activities, and AAP has been heavily interested in dakwah as well as in the construction or reconstruction of Islamic education buildings and mosques. There are two main programmes that AAP has so far focused on, namely renovation of mushalla (Ar. Musalla) and reconstruction of madrasah and worship buildings. First, 'renovation of mushalla' is a programme designed to provide a better and more reliable place of worship existing within pesantren and Muslim communities. Since 2007, AAP has built, renovated, and rebuilt 20 places of worship in certain areas of Java. Through this programme, this zakat agency attempts to mobilise domestic funds originating from zakat, and sedekah as well as to optimise the mobilisation of cash waqf (endowment). Under the concept of cash waqf, urban Muslims may invest their wealth for social and religious purposes in rural areas where madrasah and mosques are being built. Second, 'reconstruction of madrasab and worship building' intends to renovate the buildings of Islamic schools and mosques which have major damage caused by age and man-made or natural disasters. The operation of AAP in Gunung Sitoli is a materialisation of AAP's programme, namely Al-Azhar Peduli Muslim Nias, in cooperation with the YPMN in Nias. ${ }^{12}$ YPMN, a Jakarta-based foundation for Nias Muslims, as we shall see in the subsequent section, has played a pivotal role in giving Muslim communities in Nias access to funding, zakat agencies, and social institutions in Java that are able to contribute to the development of Muslim communities in Nias.

In a small hilly village in the district of Botomozoi, the AAP has reconstructed a mushalla (small place of worship) and supervised the mu'allaf (recent Muslim converts). This village is about 20 kilometres from the town of Gunung Sitoli. There is no public transportation to reach this area. One must start by travelling on the main roads, which

${ }^{11}$ HAMKA, the nickname of Haji Abdul Malik Karim Amrullah, is one of the wellknown figures of Al-Azhar, and HAMKA became the first Chairperson of the Indonesian 'Ulama Council (MUI).

12 Care Newsletter, Al-Az̧har Peduli Ummat, Edisi 12/III (Mei-June 2008/Jumad al-Akhir 1429 H), p. 14. 
have been largely destroyed by earthquakes and landslides, and then one must walk or use a motorcycle to reach the village. Along the way to district of Botomuzoi from the town of Gunung Sitoli, we may find precipitous roads and seriously damaged bridges. Despite its location inside district of Botomuzoi, the village also neighbours other districts such as Alasa, North Mandrehe, and Hili Serangkai. The mushalla 'AnNur' has just recently been established by Muslim converts among the villagers. The initiative was started in 2007 by Ama Niska, ${ }^{13}$ who converted to Islam from Christianity when he was working in North Sumatra and married a woman with (Batak) Karo ethnicity. Ama Niska's relatives remain Christian, but this has not caused any serious barrier between Ama Niska's family and others. ${ }^{14}$ Overall, there are fifteen Muslim families able to attend this mushalla regularly or irregularly. Four of the families are from this village; others come from different villages and even neighbouring districts. One attendant, Ama Jernih, for example, had to ride a motorcycle and passed through hilly fields to reach this mushalla from his home in district of Lasara. Meanwhile, Ama Ope who resided in the hills had to walk 5 kilometres from his home to the mushalla, because his home cannot be reached by public transportation or car or even by small motorcycle.

Those who live far from the mosque usually come to the mushalla on Friday at noon in order to attend the Friday Congregation (Shalat Jum'at) and they bring all their family members. For them, this small mushalla is not only a place where they can listen to the sermon of the ustädh (religious teachers), but also a place where they can share and communicate with other fellow Muslim converts. They wear Muslim dress, with baju koko and peci/kopiah (hat) for males and jilbab (veil) for females. Afterward, all congregation participants will have lunch inside the mosque during which time they may share their daily experiences with each other. Shortly after lunchtime, the mu'allaf families continue

13 In Nias, one may identify a married man or woman using 'teknonym', instead of proper names. Therefore, Ama Niska means 'the father of Niska', and Ina Niska means 'the mother of Niska'. In certain region of Nias, it is considered impolite to address adult or married people by their proper names. For further discussion about the relationship terminology of Niasan families and clans see Andrew Beatty, Society and Exchange in Nias, pp. 81-97.

14 The only problem to be faced by Muslim families, including Ama Niska and other Muslim converts, is the use of pigs in all family events and cultural festivals, as Muslims family avoid the consumption of pork. 
to chat on the mushalla's veranda while their children study the Qur'an inside the mushalla under the supervision of an ustadh from the office of Religious Affairs of Gunung Sitoli Regency. It is not always easy for these families to attend this mushalla, because they have to bring their children who, at that time, are supposed to be in school.

One family told me that he often asked the teacher's permission and picked up his children from school every Friday around two hours before Friday Congregation time in order to be able to come to the mushalla and 'Friday School'. As he explains, this is the way in which he negotiates with the school in the village not to force his children to attend the Christian 'Sunday School'. Apart from this, the ustadh has introduced Muslim converts to the Ordinance on National Education System (Undang-Undang Sisdiknas), that one of its article concerns teaching on religion at schools. Accordingly, students have the rights to be taught the religion that they and their families adhere to. On the subject of religion, for instance, Muslim children should be taught by Muslim teachers about Islam even though they study in a Christian school, and vice versa; Christian children should have subject on Christianity instead of studying Islam despite his study in Islamic schools. In practice, this issue remains a matter of dispute and is being practiced inconsistently either by Muslim or Christian Schools. In Nias, because the Christian schools in the village cannot provide Muslim students with Muslim teachers to tutor them about Islam, the Muslim families have attempted to negotiate with the school so that the school can allow Muslim children to attend 'Friday School'.

Apart from providing support to Muslim converts in Botomuzoi, AAP and the YPMN have tried to revitalise the Al-Furqan Mosque in Gunung Sitoli in which an 'Afternoon Islamic Kindergarten' (TPA) has been vividly active for many years. About two hundred children study the Qur'an through reading and writing, and memorise short verses from the Qur'an and Muslims' daily prayer narrations (doa-doa barian) in this Mosque every afternoon, from $16.00 \mathrm{pm}$ until $19.00 \mathrm{pm}$. The students are divided into different classes, depending upon their age and level of knowledge. Some ustadh organising and teaching at this Mosque are those teaching in the Islamic MIS of Nahdlatul Ulama. Otherwise, they are volunteers active in Islamic associations or members of Mosque Youth activists (aktivis remaja masjid). Al-Furqan Mosque with its emergency building was and has been quite essential to Muslim communities in Gunung Sitoli district as it is located in the 
centre of the town. Positioned right beside the Police Office of Gunung Sitoli, Al-Furqan Mosque is also very close to the town-square (alun-alun), and therefore it is accessible from different areas of Gunung Sitoli. Like other public facilities in the region, Al-Furqan Mosque was destroyed by the 2005 earthquake, and three years later, in early 2008, it has remained in its emergency building. ${ }^{15}$ Meanwhile other mosques, with limited support from the government and from NGOs, are struggling for adequate reconstruction. It is under these circumstances that the YPMN and AAP took the initiative to build the new and more comprehensive Al-Furqan Mosque, with a budget plan amounting to IDR 3.4 billion.

In financing this project, AAP and YPMN do not work alone. Instead, they engage other powerful institutions such as Dewan Masjid Indonesia (DMI-Indonesian Mosque Board), private and Governmentowned corporations, and the Forum Zakat with its associates. ${ }^{16}$ Having been successful in previous projects of mosque and mushalla reconstructions in various regions of Indonesia, AAP with the support of other charitable institutions has made the decision to run this prestigious project for a variety of reasons, one of which is related to giving culture to Indonesian Muslims. According to the staff of AAP, mobilising domestic funds for the purpose of building mosques is relatively easier than for, for example, income generating projects. The majority of Muslims in Indonesia, as in other countries, believe that donating some portions of their wealth to building mosques is a spiritually worthy activity. ${ }^{17}$ AAP often received calls from donors who inquire about the project of mosque reconstruction outer islands or isolated-regions, whereas this does not happen for micro-finance projects. Therefore, the committee members of mosque reconstruction come to believe that they will not face a great deal of difficulties in

${ }^{15}$ It should be noted the Grand Mosque of Gunung Sitoli is located not in the city centre, but in Mudik village. Receiving a lot of funds from local government, domestic and international NGOs, the Grand Mosque can promptly be rebuilt

${ }^{16}$ Forum Zakat is composed of both the government-sponsored rakat bodies (BAZ) and community-based rakat agencies throughout Indonesia. Forum Zakat was established in 1997 by a number of private zakat agencies in cooperation with government-sponsored zakat bodies. The overarching aim of the Forum Zakat is to bridge the gap and to intensify communication among zakat agencies in their dealing with rakat matters, such as regulation, mobilisation distribution and development.

17 Interview with director and staff of Al-Azhar Peduli, December 23, 2008, and January 6, 2009, in Jakarta. 
raising the required fund. In addition to this, there has been a new trend within corporations in Indonesia to channel their 'social fund', legitimated by the concept of Corporate Social Responsibility (CSR), to zakât agencies in order to finance social and religious enterprises. It should be noted that although the existing rakat agencies in Indonesia are competing 'against' one another in terms of mobilising domestic funds, they, to a certain extent, have been able to build synergy with other institutions and to fruitfully execute at least one prestigious project.

\section{DDII and AMCF: Dakwah and the Struggle for Development Projects}

Other important players in dakwah activities on the outer island are DDII and AMCF. Along with other Islamic associations such as Muhammadiyah and Nahdlatul Ulama, DDII has a long experience in carrying out dakwah activities in isolated regions. Since the 1970s, Natsir, the founder of DDII, created dakwah programmes for assisting mu'allaf (Muslim converts) and Muslim communities in transmigration areas. Meanwhile, AMCF (Asian Muslim Charity Fund) of the United Arab Emirates is one the prominent international Islamic charitable organisations that have set up branch offices in Indonesia. They are frequently involved in social services, either by creating their own programmes or by establishing partnerships with domestic Islamic charities and other Islamic civil society organisations. For example, the AMCF, which specifically works on dakwah, welfare and education, ${ }^{18}$ has cooperated with certain Islamic associations in Indonesia, notably

18 In the field of education, AMCF has strongly sponsored the establishment of Ma'bad 'Ali (Islamic Higher Education Institution). Ma'bad 'Ali of the AMCF have operated in, among other things, Muhammadiyah University of Yogyakarta and Muhammadiyah University of Surakarta. A new Ma'bad 'Ali is going to be set up in Muhammadiyah University of Sumatra Barat, West Sumatra. Meanwhile, in Bandung, West Java, the AMCF has cooperated with the PERSIS. There is no evidence that the AMCF has founded a partnership with NU. This is probably because the AMCF believes that Muhammadiyah and PERSIS have a similar ideology, that is, puritan ideology. Moreover, the AMCF has recently run various projects, including building 850 mosques and 15 Arabic and Islamic Higher education institutions throughout Indonesia. For an overview of the development of Ma'bad 'Ali, see Marzuki Wahid, "Ma`had 'Ali: Nestapa Tradisionalisme dan Tradisi Akademik yang Hilang", Jurnal Istigra, Vol. 4, No. 1 (2005): pp. 89-112. 
modernist Muslim groups such as the Muhammadiyah and PERSIS (Persatuan Islam-the Islamic Union). ${ }^{19}$

In the past three decades, DDII has carried out and supported extensive dakwah activities of Muslim communities on the Mentawai and Siberut Islands, located off the west cost of West Sumatra. Part of the population of these two islands still holds onto pre-Islamic and pre-Christian religious traditions. ${ }^{20}$ The spread of Islam and the DDII's dakwah programmes in Mentawai is quite extensive, because West Sumatra has been heavily influenced by Islamic tradition, ${ }^{21}$ and many people from Minangkabau have migrated to this Mentawai over decades to find a new life. By contrast, Nias Island is part of the province of North Sumatra, one of the largest areas where Christians are concentrated. However, this does not mean that Islamic dakwah in Nias is less extensive than in Mentawai, as evidenced by the spread of Islamic associations and institutions in Nias since the 1970s.

DDII has paid great attention to the Muslim communities in Nias by carrying out various programs, ranging from what can be called the 'conventional' method, for example posting $d \bar{a} i$ to Nias Island, to philanthropic and development-oriented projects. In this respect, DDII has argued that channeling zakat funds to dakwah is unavoidable,

19 PERSIS is a modernist association founded in 1923 by Haji Zamzam and Haji Muhammad Yunus. It is concerned with 'purifying' Islamic practice in Indonesia. Ideologically speaking, PERSIS shares similarities with Muhammadiyah in terms of religious practices, as both can be regarded as puritan Muslim associations. However, Muhammadiyah tends to pay greater attention to welfare issues by establishing schools, clinics, orphanages and universities throughout Indonesia, compared to PERSIS, which mainly focuses on education by establishing pesantren in West Java. For an account of the profile of PERSIS, see Howard M. Federspiel, Persatuan Islam: Islamic Reform in Twentieth Century Indonesia (Ithaca: Cornell University Modern Indonesia Project, 1970); Deliar Noer, The Modernist Muslim Movement in Indonesia 1900-1942 (Kuala Lumpur: Oxford University Press, 1973); Achmad Minhaji, Abmad Hasan and Islamic Legal Reform in Indonesia (1887-1958) (Unpublished Ph.D. Dissertation, McGill University, Montreal, May 1997).

${ }^{20}$ See for example, Mas'oed Abidin, Islam dalam Pelukan Mubtadin: Mentawai 30 tabun Perjalanan Dakwah Ilallah, Mentawai Menggapai Cita-cita Iman 1967-1997 (Jakarta: Dewan Dakwah Islamiyah, 1997).

${ }^{21}$ For the development of Islam in West Sumatra, see for example Reek Colombijn, "Islamic Influences on Urban Form in Sumatra in the Seventeenth to the nineteenth Century," Indonesian and the Malay World, vol. 32 (2004): 249-270; in the 1950s, Minangkabau had become the basis of PRRI Rebellion led partly by Mohammad Natsir. See Daniel F. Doeppers, "An Incident in the PRRI/Permesta Rebellion of 1958,” Indonesia, issue 14 (1972): pp. 183-195. 
because dakwah activities among isolated tribes (suku terasing) require a lot of financial support. It has also suggested that overlooking the existence of mu'allaf and new Muslim communities in isolated-regions will result in a weakening of brotherhood (ukbunwa) among Indonesian Muslims. In order to provide adequate human resources for assisting the mu'allaf, DDII in 2003 offered scholarships and training for people to go to isolated regions, namely Jamá $a b$ al-Mubtadin ('the rightly guided society').22 This jamāab consists of young people who were trained on Islam and then sent to isolated regions for dakwah, to mean providing spiritual guidance for Muslims or perhaps effort to convert indigenous people who still adhere to indigenous religions.

It is worth emphasising that the DDII's zakat agency appears to have specialised in dakwah instead of, for example, healthcare or economic development projects. Most of DDII's cadres sent to isolated regions were not equipped with skills to organise community development and livelihood projects. The $d \bar{a}^{\prime} i$ whom I encountered during my fieldwork express their opinions that dakwah is not supposed to be restricted to the despatching of preachers. This is partly because Islamic dakwah associations are now challenged by the hardships in society. Therefore, Islamic dakwah associations should be able to provide more sophisticated and well-prepared economic development and livelihood projects. They believe that the establishment of Islamic Financial Cooperatives (Bait al-Măl wa alTamwil-BMT) that can support microfinance project will be essential to poverty alleviation programs within Muslim communities (umma).

BMTs have proliferated throughout Indonesia since the 1990s along with the emergence of the first Islamic bank, Bank Muamalat Indonesia (BMI). This originated from Muslims' concern about bank interest and whether or not conventional banks, with the concept of interest, is in line with Islamic principles of economics. Between 1990 and 2000 the numbers of BMTs in Indonesia have moderately increased, reaching 3000 units with small assets of about IDR 1.5 trillions. Unlike banks, the establishment of BMTs has very often been initiated by Muslim associations or social or profit-oriented institutions with Muslim workers. In recent times, rakat agencies have also set up BMTs as a means of managing domestic funds in a more productive way. Unlike on Java Island where one may find a BMT easily, there is

22 Republika, Friday, 03 October 2003. 
not one Islamic financial cooperative on Nias Island. This is not merely because Nias is a Muslim minority region, but it reflects the genera; poor development of infrastructure in the region.

By contrast, Catholics in Nias have had an extensively supervised Credit Union among villagers since 1984, officially established in 1987, in support of small and medium enterprises and economic development among rural communities. ${ }^{23}$ The Credit Union is quite popular among villagers, as it can reach creditors in isolated villages that conventional banks cannot. In certain regions, the Credit Union is even more well-liked among rural communities than the governmentsponsored bank. This is because the $\mathrm{CU}$ is, to some extent, embedded within religious institutions, such as Catholic Churches, while at the same time it offers a less bureaucratic approach which is liked by creditors among commoners, especially those working in non-formal sector areas such as farmers and craftsmen in small villages. ${ }^{24}$

Despite the fact that economic development projects have not become a major concern for Islamic charitable institutions and zakat agencies that operate in Nias, local actors and volunteers have played quite unique roles in arranging the charitable programmes of zakat agencies in order to avoid overlapping activities. As mentioned previously, under the supervision of local volunteers, AAP can pay attention to the reconstruction of mosques and mushalla on Nias, while DDII can focus on strengthening education activities of madrasah. Volunteers consisting of local counterparts of the YPMN and mosque youth activists, have, for example, included some madrasah teachers in the training for Nias Community Development. Following this, the

${ }^{23}$ The inception of the Catholic Credit Union (CCU or CU) cannot be detached from Catholic Missionaries from North Sumatra such as Pastor Fidelis Sihotang and Mr. K.R. Situmorang. Supported by 110 employees, the Credit Union, which has since 2002 been renamed the Rural Development Co-operative (KSP3), manages 21 branches with 48,698 members and total assets of IDR 117.8 billions. http://ksp3nias.com/en/index.php

${ }^{24}$ Credit Union projects have been implemented in various regions, notably among poor rural areas. See other related cases studies Marcell D. Lodo, Bangun Solidaritas, Selamaytkan Tradisi Suku Dayak: Kisah Sukses Credit Union Pancur Kasih, Pontianak, Kalimantan Barat (Jakarta and Surabaya : Center for Economic and Social Studies, and Jawa Pos Institute of Pro-Otonomi, 2005); Ary Wahyono, Study Kasus Koperasi Credit Union "Sejabtera", Cibinong Jawa Barat: Konsep Fungsi Ganda dan Masalah Pengembangan Koperasi di Indonesia (Jakarta: LIPI, 1989). 
DDII's zakāt agency distributed a set of computers to the some madrasab in other regencies in the training.

\section{The Informal Networks and Charitable Work}

The functions of networks and the roles of local counterparts in Nias are instrumental in supporting charity activism run by domestic and international charitable organisations. Network means the linkage between individuals and institutions that hold similar objectives. The scopes of a network can be local, regional, domestic or international in character. Local institutions may have close ties with domestic NGOs and may be supported by international NGOs. When domestic and international humanitarian or religious-based associations operate in isolated regions to cater to those facing crises, they normally engage local counterparts. This strategy is often used as a means of overcoming any problems the NGOs may face, such as resistance from local figures or institutions who may feel that they are being overlooked by the foreigners. Therefore, relief missions by domestic and foreign NGOs in disaster-affected areas have often been characterised by cooperation between local, domestic, and international actors. This section will highlight the function of informal networks among ustädh and local volunteers who have been able to connect local, domestic and international actors and their charity activism. For the purpose of this work, the term 'informal network' means the informal ties and cooperation between one person and another based on common ground and shared values, rather than a formal organisational relationship.

There are several volunteers with various backgrounds on Nias Island who work together in the field to carry out Islamic dakwah or various social enterprises and religious activities. The first consists of local people who are often involved in the activities of the YPMN, either formally or informally. These people are not always included in the structure of the YPMN organisation, but, consisting of former Muhammadiyah associates and Muslim youth activists. The second group comprises ustadh appointed by AAP. The third group is composed of $d \bar{a} i$ appointed by AMCF, DDII, Hidayatullah Foundation $^{25}$ to assists Islamic dakwah in Nias Island. There were a

25 The Hidayatullah Foundation was founded in 1973 by Ustadz Abdullah Said, a former Muhammadiyah and Darul Islam activist from South Celebes. On the Hidayatullah network, see Martin van Bruinessen, "Traditionalist and Islamist 
number of young Muslims who had been assigned as $d \bar{a}^{\bar{c}} i$ in different districts throughout Nias, Batu and Mentawai Islands. It is worth noting that these $d \bar{a} i$ were predominantly attached to Muhammadiyah institutions, such as schools, orphanages and mosques. This is because, as mentioned previously, Muhammadiyah and AMCF have cooperated in sending mujahid dakwah (dakwah activists) to isolated regions. ${ }^{26}$ In the field, the overarching role of AMCF's $d a^{\bar{a}} i$ is as religious teachers, giving regular religious sermons in mosques, becoming the Imam of a mosque, and teaching children about the Qur'an. While they regularly receive limited monthly salaries from AMCF, some mujabid dakwah are also appointed as Islamic teachers at the Muhammadiyah Islamic schools, as housemasters of the Muhammadiyah orphanage, or as an imām of the Muhammadiyah mosques (Masjid At-Taqwa). ${ }^{27}$

The majority of the mujahid dakwah are fresh graduates, the alumni of Islamic higher education institutions in Java, such as Ma'had 'Ali, LIPIA, and the like. Their skill in Arabic and ability to memorise and understand the Qur'an are instrumental in supporting religious activities among Niassan Muslims. It is widely known that Ma'had 'Ali and LIPIA require students to speak Arabic fluently and to memorise certain Qur'anic chapters (juz). At the same time, AMCF has also applied certain mechanisms in recruiting prospective mujahid dakwah, and the prospective candidates were urged to fulfil the required skills: speaking Arabic, memorising the Qur'an and being acquainted with certain Islamic sources (kitäb). Therefore, AMCF's preachers usually speak Arabic when meeting up with other preachers appointed by the same institution. They also attempt to learn local language once they

Pesantren in Contemporary Indonesia," in Farish Noor, Yoginder Sikand, Martin van Bruinessen, The Madrasa in Asia: Political Activism and Transnational Linkage (Amsterdam: Amsterdam University Press, 2008), pp. 235-6.

26 Although the Central Board of Muhammadiyah and AMCF has cooperated formally, it does not mean that organisational structure and procedure can function properly at the grassroots level. In fact, the arrival of AMCF's da' $i$ has not been organised formally by the Muhammadiyah District of Nias. Instead, they came directly to sub-districts to meet local Muhammadiyah leaders.

27 On Nias Island and perhaps on other islands, most of the Muhammadiyah mosques, if not all of them, are named 'At-Taqwa'. Therefore, if a mosque has the name 'AtTaqwa', it almost certainly belongs to Muhammadiyah. 
arrived in Nias. Before beginning work in the field, the selected candidates are trained for three to six months. ${ }^{28}$

In the field, most of $d \bar{a}^{\bar{c}} i$ live modesty and earned small amount of money from their funding, just to cover their low living expense. Some of $d \bar{a} i$ were staying in small rooms beside mosque mibrab (a place for the imam to lead prayer). As the construction and the design of mosque on the outer island such as Nias is not as fashionable as in big cities, in many cases the rooms where $d \bar{a} i$ reside are very modest with limited space, just sufficient to fit a carpet for their sleep and put some clothes and books. They are very often placed in unfinished mosques, and I found no electronic items such as radio or television in their room. During prayer times, they should be available to perform azan as well as lead prayer five times a day. It is within this setting they dedicated themselves for dakwah. In order to sustain such a long term programme as the mujabid dakwah in Nias, some young $d \bar{a}^{\bar{c}} i$ married local women and become part of the communities.

Informal networks can be established among Muslim activists because of their shared values and objective of assisting Muslim minorities on the island. They can work together by becoming volunteers of charitable works run by certain Islamic associations. Charitable programmes organised by DDII offers an interesting case study. This is because DDII's programmes were enthusiastically assisted by local people as well as $d \bar{a} i$ from other Islamic associations. This indicates that in the field, their shared-interest have compelled them to work together by putting differences in organisational background aside. For example, DDII's zakat agency, as mentioned previously, has attempted to strengthen the capacity of Islamic schools in rural areas by training teachers and distributing a set of computers and other school equipments and kits to Nias Island. Interestingly, DDII's zakat agency of Jakarta does not engage the office branch of

\footnotetext{
28 One $d a^{\prime} i$ told me that during his period of training there were about three hundred candidates participating in the training in Jakarta, only seventy of whom were finally assigned as ustadh in isolated-regions. It is said that during the course of pre-departure training, those da'i should take courses on general knowledge (psychology, anthropology, early emergency aid \& basic accounting) as well as Islam knowledge theoretically (Quranic exegesis, 'aqida, hadith, fiqh, and sira nabawiyya) and practically (micro teaching and funeral arrangement). Apart from this, after the training, all trainee da'i received 'standard' Islamic books in Arabic such as Ibn kathìr, riyā al al-sălihịin, fath almajīd, fiqh al-sunna, al-targhīb wa al-tarbīb, etc.
} 
DDII in Gunung Sitoli. Instead, it appoints local Muslim activists, the volunteers of the YPMN, who have no organisational relationship to the DDII's office in Nias. In distributing the computers from Gunung Sitoli to Islamic school in other districts, such as Bizehena and Lahewa, for example, not one DDII activist was involved. Instead, the arrival of the team from Gunung Sitoli was prepared by the AMCF's $d \bar{a} i$ and local mosque youth activist (remaja masjid).

\section{FOSDAN (Forum Silaturahmi Da'i Nias)}

My second visit to Nias Island in October 2010 revealed a new development of dakwah activities on Nias Island. This partly is marked by establishment of a new association, namely Forum Silaturabmi Da'i Nias (FOSDAN). Despite the fact that these da'i are sponsored by different funding, a number of da' $i$ realise that a sort of association, through which an effective and more organised collaboration can be initiated, is indispensable. In February 2010 FOSDAN was founded. ${ }^{29}$ The reason behind the rise of FOSDAN is that these preachers wish for making broader change on Nias Island not only religiously but also socially and economically. It is reflected in their daily discourse that social welfare activities and economic development projects should be included in strengthening the umma and in turn the society as a whole. So that dakwah activism can touch the real social problems and economic hardship that communities have faced. In a nutshell, dakwah, in their interpretation, should not be restricted to the 'conventional preaching', but must be augmented with other activities that can cover society needs at large.

As FOSDAN becomes the 'informal' umbrella of $d \bar{a}^{\bar{c}} i$ volunteers in Nias, communication between $d \bar{a} i$ can ever more be intensified, and thus their dakwah activities can be expanded. They started publishing a weekly-bulletin, called "Ad-Dakwa", through which $d \bar{a} i$ can disseminate information about Islam by writing short popular articles, as well as can provide opportunity for the readers among Niassan Muslims to raise questions about Islam. The social condition on Nias Island which has heavily been characterised by local Nias indigenous culture and Christian tradition makes the questions to be raised by the people far more varied, dealing not only with the normative theological

${ }^{29}$ It consists of Muslim preachers whose presence in Nias was sponsored by different parties, such as AMCF (13 preachers); DDII (2); Hidayatullah (5); and AAP (1). 
matters but also with the interfaith issues. As we have acknowledged that many Niasan Muslims are converts whose relatives remain adhering Christianity and thus practicing local tradition. One of the readers was questioning about the extent to which Muslims in Nias can establish appropriate relationship with non-Muslim relatives. More precisely, he asked FOSDAN Bulletin whether it is acceptable according to Islam to present a swine in order to respect his Christian relatives. On Nias Island, presenting big and expensive swine symbolises honour and respect. In many cases, Muslim converts cannot avoid tradition of presenting swine thank to their good relationships with their Christian relatives. They wanted to practice Islam properly but at the same time hesitated to detach from tradition which has embedded in society, as well as attempted to preserve cohesion among families.

In response to that case, the $d \bar{a} i$ that affiliated to FOSDAN suggest that in the context of Nias society, presenting swine in order to respect non-Muslim extended families are permitted on condition that the givers (Muslims) do not consume the gift (swine). Presenting gift in form of a swine is only a means to strengthen relationships and to preserve the unity of families. Islam, as FOSDAN $d \bar{a}^{\bar{\epsilon}} i$ have explained, is contextually "applied in every time and place". Islam also put emphasis on the necessity to establish good vertical relations with God ( abl min Allāh), and horizontal relations with human beings ( habl min al-nass) alike. In this respect, presenting swine may represent endeavour to make good horizontal relations, not to violate God's orders. The answer of $d \bar{a}^{\bar{c}} i$ to the local Muslim's query about a socially embedded interfaith issue above reflects a paradigm shift among young $d \bar{a}^{\overline{6}} i$ in understanding the complexity of live of Muslim living in a non-Muslim populated region, such as Nias. Yet this kind of answer is not coming out instantly, as FOSDAN da $\bar{a}^{\bar{c}} i$ have to discuss it carefully and to find justification from authoritative sources. This is simply because they wanted to give wise answer by not using strict and clear-cut approach to the problem faced by society, even though during the course of predeparture training in Jakarta these $d \bar{a} \bar{i}$ were trained in a religiously very strict environment.

\section{Conclusion}

It is hard to deny that charity activism has simply been part of dakwah. As a framework, Islamic dakwah is strongly embedded in many 
kinds of activities run by Muslims. At the same time, activism charity and social welfare enterprises activism can also be regarded as a tool for implementing the five pillars of Islam. The giving of alms, for example, is not only a spiritual obligation for Muslims, as it impacts on the social life of the Muslim community. The establishment of mosques and mushalla (a small building in a public space for performance of religious duties) in Muslim minority regions funded and supervised by zakāt agencies tends to intensify religious practices, such as praying, weekly Friday sermon, studying the Qur'an and, in a larger context, studying Islam and maintaining religious identity. Dakwah and charity activism can also be seen as the way in which rakat agencies and dakwah associations strengthen social cohesion and help to fortify their religious commitment among new Muslim converts in Muslim minority regions.

It should be stressed that Islamic associations have created rakat agencies in order to specifically support their dakwah activities in both rural and urban areas. Others have even gone further by specifically working on the outer islands. In practice, there are two kinds of dakwah: dakwah among Muslims and dakwah among non-Muslims. The former, dakwah among Muslims, can mean the process of Islamisation in society. As a legitimate Islamic key concept in Muslim societies, dakwah is and can be applied in various sectors: social, cultural, economic, and political. Nevertheless, the way in which Muslim activists put the concept of dakwah into practice is not always the same. The modernist Muhammadiyah and PERSIS have particular conceptions that may differ from the 'traditionalist' NU conception of what Islamic society should be. The modernist mission has been predominantly characterised by the notion of 'purification', while the traditionalist one seems to have been adaptive to local cultures. The latter concept, dakwah among non-Muslims, is not as popular as the former, dakwah among Muslims, and some Islamic associations have included this concept of dakwah in their organisational programmes. Practically, dakwah among non-Muslim bears some resemblance to Christian missionary activities in non-Christian populations.

Dakwah associations are targeting both Islamic formal and nonformal education institutions, such as Islamic madrasah, mosques and mushalla. It is worth noting further that, as explained previously, mosques and mushalla can be used for multiple purposes, ranging from performing Islamic rituals to educating Muslim children. The lack of 
adequate formal Islamic education institutions, particularly in Nias, has resulted in the increase of role played by mosques and mushalla as informal Islamic educational institutions. Strengthening the institutional capacity of a mosque can mean providing communities with more adequate informal education institutions. For that purpose, zakāt agencies and dakwah associations have channeled their funds collected from domestic sources to support Islamic dakwah and education, especially in isolated regions, rather than to providing healthcare or basic needs of communities, as have mostly been received by poor urbanites.

In order to specify the characteristics of Islamic charities and dakwah activism in a Muslim minority region we may explore the extent to which Islamic charitable associations and dakwah associations can or cannot work with other non-Islamic associations in Nias, notably Christian associations. This issue becomes interesting because charitable associations and rakat agencies such as AAP, DDII, and AMCF are not based in Nias. Rather, Nias is simply a place where they operate social and religious services. They appear in Nias, representing internal Muslim solidarity, to support Muslim minority groups in the region. The absence of non-Muslims as beneficiaries of the above zakat agencies and charitable institutions seem to be a result of the characteristic of project-based dakwah programmes, not a general concept of humanitarianism. Resource mobilisation by zakat agencies and dakwah associations, including their campaigns in the mainland during the process of raising funds, is solely intended to support minority groups in Nias who, according to the associations, have encountered difficulties following the 2005 disaster. However, we should also note that in practice the term mu'allaf is often contested, as it may consist of various meanings, such as 'prospective converts', 'those who are sympathetic about Islam', 'new Muslim converts', or 'those Muslims who are less knowledgeable about Islam' due to a less 'Islamic environment'.

A more lasting development appears that delivering aid to isolated regions requires solid networks with local counterparts. Informal networks and informal actors or volunteers to some extent play more effective roles in arranging and managing charitable works than formal organisational structures do. These informal volunteers have increasingly underpinned charity and zakat movements in the field as, evidenced by the roles of the AMCF's ustädh, AAP's Da'i Sababat 
Mustabik, and the DDII's volunteers among Niasans. It should also be noted that the Muhammadiyah, AAP, DDII and the Hidayatullah Foundation all offer examples of how Islamic associations can extend their working areas of dakwah. Stimulated by the notion of solidarity between the members of the umma, these associations operate in the outer islands to assist Muslim minority groups who might need assistance from outside, due to their poor living conditions or because their regions have suffered from social, economic or political neglect. The lack of places of worship, the shortage of adequate educational institutions and skilled worker development training, and more importantly, the scarcity of knowledgeable persons or religious scholars who can teach them to learn and can guide them in the practice of Islamic teaching, all justify Muslim NGOs operating in isolated regions. As matter of fact, local people are in need of these young, dedicated and devout Muslim preachers from the abovementioned associations, as they play multiple roles (Islamic teachers in schools, language teachers [English or Arabic], mosque organisers, etc.) in the outer islands, where only a few Muslim converts live.]

\section{Bibliography}

\section{Books and Articles}

Abidin, Mas'oed. Islam dalam Pelukan Mubtadin: Mentawai 30 tabun Perjalanan Dakwahh Ila'llah, Mentawai Menggapai Cita-cita Iman 1967-1997 (Jakarta: Dewan Dakwah Islamiyah, 1997).

Beatty, Andrew. Society and Exchange in Nias (Oxford: Oxford Studies in Social and Cultural Anthropology, 1992).

Bruinessen, Martin van. "Genealogies of Islamic radicalism in postSuharto Indonesia", South East Asia Research vol. 10, No. 2 (2002), pp. 117-154.

--------, "Traditionalist and Islamist Pesantren in Contemporary Indonesia," in Farish Noor, Yoginder Sikand, Martin van Bruinessen, The Madrasa in Asia: Political Activism and Transnational Linkage (Amsterdam: Amsterdam University Press, 2008), 217-246.

Colombijn, Freek. "Islamic Influences on Urban Form in Sumatra in the Seventeenth to the nineteenth Century," Indonesian and the Malay World, vol. 32 (2004), 249-270 
Doeppers, Daniel F. "An Incident in the PRRI/Permesta Rebellion of 1958," Indonesia, issue 14 (1972), pp. 183-195.

Federspiel, Howard M. Persatuan Islam: Islamic Reform in Twentieth Century Indonesia (Ithaca: Cornell University Modern Indonesia Project, 1970)

Hummel, Uwe and Tuhoni Telaumbanua, Cross and Adu: a SocioHistorical Study on the Encounter between Christianity and the Indigenous Culture on Nias and the Batu Islands, Indonesia (1865-1965) (Zoetermeer: Boekencentrum, 2007).

D. Marcell D. Lodo, Bangun Solidaritas, Selamatkan Tradisi Suku Dayak: Kisah Sukses Credit Union Pancur Kasib, Pontianak, Kalimantan Barat Jakarta and Surabaya: Center for Economic and Social Studies, and Jawa Pos Institute of Pro-Otonomi, 2005)

Minhaji, Achmad. "Ahmad Hasan and Islamic Legal Reform in Indonesia (1887-1958)”, Ph.D. Dissertation, McGill University, Montreal, May 1997.

Noer, Deliar. The Modernist Muslim Movement in Indonesia 1900-1942 (Kuala Lumpur: Oxford University Press, 1973)

Steenbrink, Kareel. Catholics in Indonesia 1808-1942, vol. I (Leiden: KITLV Press, 2003).

Suryadinata, Leo, et al. Indonesia's Population: Ethnicity and Religion in a Changing Political Landscape (Singapore: ISEAS, 2003).

Suzuki, Peter T. Critical Survey of Studies on the Anthropology of Nias, Mentawei and Enggano (Leiden: KITLV, 1958)

Wahid, Marzuki. "Ma had 'Ali: Nestapa Tradisionalisme dan Tradisi Akademik yang Hilang", Jurnal Istiqra, Vol. 4, No. 1 (2005), pp. 89-112.

Wahyono, Ary. Study Kasus Koperasi Credit Union "Sejabtera", Cibinong Jawa Barat: Konsep Fungsi Ganda dan Masalah Pengembangan Koperasi di Indonesia (Jakarta: LIPI, 1989).

Zubir, Goodwill and Sudar Siandes, Potret Gerakan Kristenisasi di Indonesia Versi Dai LDK Mubammadiyah (Pimpinan Pusat Muhammadiyah: Lembaga Dakwab Khusus, 2005). 